\title{
Impact of Seminal Plasma Trace Elements on Human Sperm Motility Parameters
}

\author{
MOHAMMAD MOSTAKHDEM HASHEMI ${ }^{1}$, NASSER BEHNAMPOUR ${ }^{2}$, MOJGAN NEJABAT $^{3}$, AFSANEH TABANDEH $^{4}$, \\ BEHROUZ GHAZI-MOGHADDAM ${ }^{4}$, HAMID REZA JOSHAGHANI $^{5}$
}

\author{
${ }^{1}$ Metabolic Disorders Research Center, Golestan University of Medical Sciences, Gorgan, Iran \\ ${ }^{2}$ Health Management and Social Development Research Center, Golestan University of Medical Sciences, Gorgan, Iran \\ ${ }^{3}$ Department of Medicinal Chemistry, Faculty of Pharmacy, Mashhad University of Medical Sciences, Mashhad, Iran \\ ${ }^{4}$ Golestan University of Medical Sciences, Gorgan, Iran \\ ${ }^{5}$ Laboratory Sciences Research Center, Golestan University of Medical Sciences, Gorgan, Iran
}

\begin{abstract}
Introduction. Human seminal plasma contains a variety of macro and trace elements including magnesium $(\mathrm{Mg})$, copper $(\mathrm{Cu})$, zinc $(\mathrm{Zn})$, and iron $(\mathrm{Fe})$ that have essential roles in normal functioning of semen and its quality. The imbalance of these elements has been reported in several pathologic and male infertility disorders. Therefore, this study aimed to determine the levels of these elements in seminal plasma samples, their relationships with each other and their impact on sperm motility.

Methods. Overall, 192 males (96 normospermic and 96 asthenospermic males) were enrolled in the study. Semen samples were collected by masturbation and computer-assisted/aided semen analysis of sperm motility was performed. The samples were centrifuged and seminal levels of $\mathrm{Mg}$, $\mathrm{Cu}, \mathrm{Zn}$ and $\mathrm{Fe}$ were measured using atomic absorption spectroscopy.

Results. The levels of $\mathrm{Zn}$ did not differ between the two groups, while the levels of $\mathrm{Mg}, \mathrm{Cu}$, and $\mathrm{Fe}$ were significantly higher in normospermic males. Fe showed a positive correlation with $\mathrm{Mg}$ and $\mathrm{Cu}$ in asthenospermic group. However, a negative relationship was found between $\mathrm{Mg}$ and $\mathrm{Fe}$ levels and between $\mathrm{Mg}$ and sperm concentration in the normospermic group. Fe levels were higher in the normospermic group compared to the asthenospermic group. Nevertheless, increased Fe levels caused a decrease in most of sperm motility fractions.

Conclusion:Elements play major roles in male fertility and directly affect sperm quality. According to the results of this study, the levels of $\mathrm{Zn}$ do not affect the sperm quality and motility, while $\mathrm{Fe}, \mathrm{Cu}$ and $\mathrm{Mg}$ are decreased in males with sperm motility problems. Nevertheless, Fe levels can adversely affect sperm motility in normospermic men.
\end{abstract}

Key words: sperm motility; magnesium; copper; zinc; iron.

\section{INTRODUCTION}

Human seminal plasma contains a variety of macro and trace elements including magnesium $(\mathrm{Mg})$, copper $(\mathrm{Cu})$, zinc $(\mathrm{Zn})$ and iron $(\mathrm{Fe})$ that have essential roles in normal functioning of semen and its quality [1-4]. $\mathrm{Mg}$ is required as the main cofactor for kinase enzymes [5] and acts as an intracellular calcium (Ca) antagonist [6]. Increased $\mathrm{Mg}$ levels compared to $\mathrm{Ca}$ improve erection and ejaculation processes [7]. $\mathrm{Cu}$ is an important component of many metaloenzymes such as superoxide dismutase (SOD), ceruloplasmin and lysine oxidase that are crucial in energy metabolism pathways and antioxidant processes [8]. However, it can be toxic to a variety of cells even spermatozoa [9].

$\mathrm{Zn}$ has an important role in sperm motility and directly affects its morphology [10, 11]. It exists in spermatozoa and seminal plasma owning the highest concentration in compare to any other body fluid [12]. $\mathrm{Zn}$ cooperates with $\mathrm{Fe}$ in oxidation- reduction processes and is involved in antioxidant reactions as the cofactor of $\mathrm{Cu}-\mathrm{Zn}$ SOD [13]. However, some studies showed no significant relationship between concentration of $\mathrm{Zn}$ in seminal plasma and sperm count or motility [14]. On the other hand, $\mathrm{Fe}$ is suspected to induce and catalyze lipid peroxidation that reduces semen quality and sperm motility [15]. Therefore, this study aimed to determine the seminal plasma levels of $\mathrm{Mg}, \mathrm{Cu}, \mathrm{Zn}$ and $\mathrm{Fe}$ in normozoospermic and asthenozoospermic men, and compare their levels to evaluate the effects of each element on sperm motility characteristics by computerassisted/aided semen analysis (CASA).

\section{MATERIAL AND METHODS}

\section{STUDY POPULATION}

This study was conducted on 192 men referred to clinical laboratories in Gorgan (northern Iran) for routine semen analysis as the primary 
approach for men fertility testing. The subjects were equally divided into two groups of cases and controls according to semen analysis results. The control group included normozoospermic subjects (producing spermatozoa normal in number, morphology, and motility) with total motility rate of $\geq$ $40 \%$. The case group included asthenozoospermic subjects with total motility rate of $<40 \%$ and normal sperm morphology and concentration.

\section{SAMPLE COLLECTION}

Semen samples were collected in sterile containers by masturbation after 3-7 days of sexual abstinence. The samples with volume of less than 2 $\mathrm{mL}$ and sperm concentration of less than $20 \times$ $10 \% \mathrm{~mL}$ were excluded. After $15-60$ minutes of liquefaction, volume and $\mathrm{pH}$ of samples were determined and manually analyzed. CASA was performed according to the WHO laboratory manual for the examination and processing of human semen. Total sperm motility and its subgroups were defined for each sample according to the categorization of WHO: motility type A (rapid progressive motile), motility type B (slow or sluggish progressive motile), motility type $\mathrm{C}$ (non-progressive motile) and motility type $\mathrm{D}$ (immotile).

The parameters assessed by CASA included: curvilinear velocity (VCL), straight-line/rectilinear velocity (VSL), average path velocity (VAP), mean angular displacement (MAD), amplitude of lateral head displacement (ALH), beat cross frequency (BCF), linearity (LIN) defined as VSL/VCL, wobble (WOB) defined as VAP/VCL, and straightness (STR) defined as VSL/VAP.

After semen analysis, the samples were centrifuged at $2500 \mathrm{rpm}$ for 10 minutes. The supernatant plasma was separated into $500 \lambda$ aliquots and stored at $-70^{\circ} \mathrm{C}$ for future biochemical testing in less than a month.

\section{SAMPLE PREPARATION}

For biochemical measurements, the samples were thawed at room temperature. The samples were then deproteinized by equal volume of $10 \%$ tricarboxylic acid. The samples were centrifuged again and the supernatants were collected as the final sample with a 1:1 dilution ratio.

\section{BIOCHEMICAL ANALYSIS}

Seminal plasma levels of $\mathrm{Mg}, \mathrm{Cu}, \mathrm{Zn}$ and $\mathrm{Fe}$ were measured using flame atomic absorption spectrometry (YOUNGLIN AAS 8020, Hogye- dong, Anyang, South Korea) at wavelengths of $285.20 \mathrm{~nm}, 324.70 \mathrm{~nm}, 213.90 \mathrm{~nm}$, and $248.30 \mathrm{~nm}$, respectively. Standard solutions (spectroECONchemlab, Zedelgem, Belgium) were used to draw standard curves according to manufacturer's instruction. The prepared samples were diluted by high purity distilled water (DW) with 1:100 ratio for $\mathrm{Mg}$ and $\mathrm{Zn}$ measurement, 1:8 for $\mathrm{Cu}$ measurement, and 1:4 for Fe measurement. All measurements were done in duplicate. The spectrophotometer was calibrated after each series of assays and the lamp was adjusted. Standard solutions with concentrations of $1 \mu \mathrm{g} / \mathrm{mL}$ (Mg and $\mathrm{Zn}$ ), $0.1 \mu \mathrm{g} / \mathrm{mL}$ $(\mathrm{Cu})$ and $0.6 \mu \mathrm{g} / \mathrm{mL}(\mathrm{Fe})$ were used for internal control. Results were reported as $\mu \mathrm{g} / \mathrm{mL}$.

\section{STATISTICAL ANALYSIS}

Analyses were performed using SPSS software version 21. Basic descriptive statistics including mean \pm standard deviation (SD) were calculated for the variables. Kolmogorov-Smirnov and Shapiro-Wilk tests were used to assess normality of the data. Two independent samples Mann-Whitney U test was performed to compare the levels of variables between the two groups.

The values of $5^{\text {th }}$ and $95^{\text {th }}$ percentile of the levels of these elements were determined according to their values in control group. Then, each group was divided into three subgroups as follows:

Low: values lower or equal to $5^{\text {th }}$ percentile, Normal: values higher than $5^{\text {th }}$ percentile and lower or equal to $95^{\text {th }}$ percentile, High: values higher than $95^{\text {th }}$ percentile. Chi-square test was used for comparing the three subgroups of two groups. P-values of less than 0.05 were considered as statistically significant.

This study was approved by the local ethics committee of Golestan University of Medical Sciences.

\section{RESULTS}

The mean \pm standard deviation (SD) age of asthenozoospermic and normozoospermic men were $31.2 \pm 5.9$ years and $30.2 \pm 5.3$ years, respectively. The mean of sperm motility and all of its parameters were higher in the normozoospermic group ( $p$-value $<0.01)$, while immotile fraction had higher percentages in the asthenozoospermic group as expected (Data are not shown). 
The mean \pm SD of the studied elements are shown in Table 1. There was no significant difference in the level of $\mathrm{Zn}$ between the two groups, while $\mathrm{Cu}, \mathrm{Fe}$ and $\mathrm{Mg}$ levels were significantly higher in the normozoospermic group than in the asthenozoospermic group ( $p$-value < $0.01)$. There was no intercorrelation between the elements and sperm motion parameters in the asthenozoospermic group. However, there was a significant correlation between Fe levels and some of these parameters in the normozoospermic group (Table 2). Fe did not reveal any correlations with sperm motion parameters in asthenozoospermic patients.

Table 1

The levels of elements in the two study groups

\begin{tabular}{|l|c|c|c|}
\hline Elements & $\begin{array}{c}\text { Normozoospermic } \\
(\text { mean } \pm \text { SD) }\end{array}$ & $\begin{array}{c}\text { Asthenozoospermic } \\
(\text { mean } \pm \text { SD) }\end{array}$ & p-value \\
\hline $\mathrm{Zn}(\mathrm{mg} / \mathrm{mL})$ & $188.42 \pm 99.61$ & $187.15 \pm 87.38$ & 0.925 \\
\hline $\mathrm{Cu}(\mathrm{mg} / \mathrm{mL})$ & $1.29 \pm 0.58$ & $1.05 \pm 0.28$ & $<0.05$ \\
\hline $\mathrm{Fe}(\mathrm{mg} / \mathrm{mL})$ & $2.02 \pm 0.74$ & $1.56 \pm 0.48$ & $<0.001$ \\
\hline $\mathrm{Mg}(\mathrm{mg} / \mathrm{mL})$ & $550.12 \pm 282.51$ & $130.94 \pm 96.75$ & $<0.001$ \\
\hline
\end{tabular}

Table 2

Correlation between Fe levels and sperm motility types in the normozoospermic group

\begin{tabular}{|l|c|c|}
\hline \multicolumn{1}{|c|}{ Motility type } & r & p-value \\
\hline Total motility & -0.253 & 0.013 \\
\hline Progressive motility & -0.215 & 0.035 \\
\hline Motility type A & -0.303 & 0.003 \\
\hline Motility type B & 0.236 & 0.021 \\
\hline Motility type C & -0.249 & 0.014 \\
\hline Motility type D (immotile) & 0.253 & 0.013 \\
\hline VCL & -0.343 & 0.001 \\
\hline VSL & -0.294 & 0.004 \\
\hline VAP & -0.326 & 0.001 \\
\hline MAD & -0.326 & 0.001 \\
\hline ALH & -0.345 & 0.001 \\
\hline STR & -0.213 & 0.037 \\
\hline
\end{tabular}

The limits of normal ranges were defined as the $5^{\text {th }}$ and $95^{\text {th }}$ percentile for the elements according to normozoospermic group values equal to 44.6 and $357.5 \mu \mathrm{g} / \mathrm{mL}$ for $\mathrm{Zn}, 0.752$ and $1.615 \mu \mathrm{g} / \mathrm{mL}$ for $\mathrm{Cu}, 0.96$ and $3.658 \mu \mathrm{g} / \mathrm{mL}$ for Fe and 106.3 and $1069.1 \mu \mathrm{g} / \mathrm{mL}$ for $\mathrm{Mg}$.

Considering these cutoffs, $45.8 \%(n=44)$ of samples in the asthenozoospermic group had $\mathrm{Mg}$ levels lower than the $5^{\text {th }}$ percentile, while only $4.2 \%(\mathrm{n}=4)$ of samples in the normozoospermic group had $\mathrm{Mg}$ levels lower than the $5^{\text {th }}$ percentile ( $p$-value $<0.01)$. However, there was no significant difference in the level of other studied elements.

\section{DISCUSSION}

This study assessed the levels of four metal elements $(\mathrm{Mg}, \mathrm{Cu}, \mathrm{Zn}$ and $\mathrm{Fe})$ in the seminal fluid of asthenozoospermic and normozoospermic men. These elements can improve sperm quality by participating in key enzymatic reactions crucial for maintaining sperm normal physiology. However, these elements may impair sperm functions by inducing oxidative stress [15].

The results of this study showed significantly lower levels of $\mathrm{Cu}, \mathrm{Mg}$, and $\mathrm{Fe}$ in the seminal fluid of asthenozoospermic subjects in comparison to normozoospermic men. No statistically significant difference was observed in the levels of $\mathrm{Zn}$ between the two groups. Although Fe levels were higher in men with normal sperm motility, it adversely affected sperm motility in this group.

A significant difference in seminal plasma $\mathrm{Cu}$ levels was observed between the asthenozoospermic and normozoospermic groups. This is inconsistent with the results of Eidi et al. [16] and Yan Li et al. [17] that reported a negative correlation between semen quality and $\mathrm{Cu}$ levels. In the study of $\mathrm{Li}$ et al., $\mathrm{Cu}$ was considered as an environmental chemical pollutant for the workers and staff of an industrial factory, while in the present study $\mathrm{Cu}$ was measured as a common metal element in 
patients who were not exposed to poisonous amounts of $\mathrm{Cu}$. In contrast to the findings of present study, Aydemir et al. showed higher levels of $\mathrm{Cu}$ in subfertile males compared to fertile males [18].

Meanwhile, Yuyan reported that levels of serum $\mathrm{Cu}$ have no impact on the sperm quality [19]. It is worth mentioning that serum samples were used in the mentioned study, while we analyzed seminal plasma samples. Moreover, it has been recently suggested that seminal $\mathrm{Cu}$ has higher potency as a sensitive indicator compared to seminal $\mathrm{Cu}$ [18].

It is thought that Fe may decrease sperm quality and motility through induction of lipid peroxidation and formation of hydroxyl radicals [20]. Although we found significantly higher levels of $\mathrm{Fe}$ in the normozoospermic group, $\mathrm{Fe}$ adversely affected most of sperm motility fractions in this group. These findings are partially in agreement with the results of Aydemir et al. that showed a positive correlation between serum levels of Fe and sperm motility while in another part of their results, they declared that seminal levels of $\mathrm{Fe}$ were higher in subfertile males than in fertile males [18]. In contrast to these results, Wróblewska et al. [21] reported the negative effect of Fe on sperm morphology. Kasperczyk reported that seminal levels of $\mathrm{Fe}$ increase in association to other metals [22]. We also observed an overall increase in three metals $(\mathrm{Cu}, \mathrm{Fe}$ and $\mathrm{Mg})$ levels in the normozoospermic group.

$\mathrm{Fe}$ is present in many enzymes and metalloprotein compounds and participates in oxidationreduction processes [15]. The antagonistic relationship between $\mathrm{Fe}$ and other metal elements such as $\mathrm{Zn}$ and $\mathrm{Cu}$ in both absorption and metabolic functions causes some difficulty in interpretation of the role of $\mathrm{Fe}$ in male infertility.

Seminal levels of $\mathrm{Mg}$ are often used to judge about premature ejaculation (PE) assessment [7]. El Aaleba and Aloosh showed similar results about the seminal levels of $\mathrm{Mg}$ levels in PE patients, indicating that PE patients had lower levels of seminal plasma $\mathrm{Mg}$ levels compared to normal men [7, 23]. Sorensen et al. reported no correlation between $\mathrm{Mg}, \mathrm{Zn}$ and $\mathrm{Ca}$ levels, while we found significant positive and negative relationships between $\mathrm{Mg}$ and Fe levels in the asthenozoospermic and normozoospermic individuals, respectively. The decline in $\mathrm{Mg}$ levels could be due to the presence of an $\mathrm{Mg}$ diminishing factor like chelating agents in the semen of the patients or a previous hypomagnesemia caused by low consumption of $\mathrm{Mg}$ [4].

There were no significant differences in the seminal levels of $\mathrm{Zn}$ between normozoospermic males and asthenozoospermic patients in the present study. However, Yuyan et al. showed that reduced serum levels of $\mathrm{Zn}$ may lead to an increased risk of asthenozoospermia [19]. It should be mentioned that Yuyan et al. analyzed serum levels of $\mathrm{Zn}$ while the current study was conducted on seminal samples which may define the observed variation between two studies. Since the present study was a retrospective analysis, we were not able to determine the risk of asthenozoospermia. Atig et al. and Saglam et al. found a significant difference in the seminal levels of $\mathrm{Zn}$ levels of normozoospermic men and patients with a pathologic spermiogram [24-26]. The case group of the study of Atig et al. included males with all types of sperm impairments (asthenozoospermic, oligozoospermic, and teratozoospermic), while the present study only investigated patients with sperm motility problems (asthenozoospermic) [24]. Consistent with the findings of the present study, Wróblewska et al. and Camejo et al. reported no notable differences in seminal levels of $\mathrm{Zn}$ between normozoospermic males, varicocele patients, and patients with a pathologic spermiogram $[21,27]$.

\section{CONCLUSION}

This study showed no significant relationship between seminal levels of $\mathrm{Zn}$ and sperm motility. $\mathrm{Cu}, \mathrm{Mg}$ and $\mathrm{Fe}$ may affect sperm motility, because of their higher levels in normozoospermic males compared to asthenozoospermic males. Fe showed adverse effects on motility when analyzed within normozoospermic males group and its certain effect still remains as a mystery to be solved. Further studies are necessary to determine the exact effect of these elements on semen quality and sperm motility.

\begin{abstract}
Acknowledgements. This study was financially supported by the deputy of research and technology of Golestan University of Medical Sciences and Health Services, Gorgan, Iran. The authors would like to thank the Department of Research at Golestan University of Medical Sciences for their financial support.
\end{abstract}

Conflict of Interest Disclosure. The authors declare that there are not conflicts of interest. 
Introducere. Lichidul seminal conţine o varietate de oligoelemente ca magneziu $(\mathrm{Mg})$, cupru $(\mathrm{Cu})$, zinc $(\mathrm{Zn})$ şi fier $(\mathrm{Fe})$. Acestea au rol esenţial în buna funcţionare a spermei şi influenţează calitatea acesteia. Dezechilibrul acestor oligoelemente poate duce la infertilitate masculină. Studiul şi-a propus să studieze asocierea dintre acest dezechilibru şi impactul asupra parametrilor motilităţii spermei.

Metode. Au fost incluşi 192 de bărbaţi (96 normospermici şi 96 astenospermici). Sperma a fost recoltată după masturbare şi a fost realizată analiza motilităţii. Probele au fost centrifugate şi au fost analizate nivelurile de $\mathrm{Mg}, \mathrm{Cu}, \mathrm{Zn}$ şi Fe prin spectrometrie de absorpţie atomică.

Rezultate. Nivelurile de Zn nu au fost semnificativ diferite intre cele două grupuri. Nivelurile de $\mathrm{Mg}$, $\mathrm{Cu}$ şi Fe au fost semnificativ mai mari la pacienţii normospermici. Totuşi, s-a observat o corelaţie negativă între nivelurile de $\mathrm{Mg}$ şi Fe precum şi între nivelurile de $\mathrm{Mg}$ şi concetraţia spermei în grupul de pacienţi normospermici. Deşi nivelurile de Fe au fost semnificativ mai mari la pacienţii normospermici, nivelurile crescute ale $\mathrm{Fe}$ s-au asociat cu scăderea majorităţii parametrilor de motilitate.

Concluzii. Oligoelementele joacă un rol important şi afectează calitatea spermei. Nivelurile de Zn nu afectează calitatea spermei însă nivelurile scăzute ale $\mathrm{Fe}, \mathrm{Mg}$ şi Cu duc la scăderea parametrilor de motilitate a pacienţilor.

Correspondence to: Hamid Reza Joshaghani MD, Laboratory Sciences Research Center,

Golestan University of Medical Sciences, Gorgan, Iran

Tel: +989111779909

E-mail:joshaghani@goums.ac.ir

\section{REFERENCES}

1. GUZIKOWSKI W., SZYNKOWSKA MI., MOTAK-POCHRZĘST H., PAWLACZYK A., SYPNIEWSKI S. Trace elements in seminal plasma of men from infertile couples. Arch med sci: AMS. 2015; 11(3):591.

2. HAMAD A., AL-DAGHISTANI HI., SHQUIRAT WD., ABDEL-DAYEM M., AL-SWAIFI M. Trace element levels in seminal plasma which associated with sperm quality in fertile and infertile men. J ReprodInfertil. 2014; 5:14-22.

3. KIZILER AR., AYDEMIR B., GUZEL S., YAZICI CM., GULYASAR T., MALKOC E., et al. Comparison of before and after varicocelectomy levels of trace elements, Nitric oxide, Asymmetric dimethylarginine and malondialdehyde in the seminal plasma and peripheral and spermatic veins. Biol Trace Elem Res. 2015; 167:172-8.

4. WONG WY., FLIK G., GROENEN PM., SWINKELS DW., THOMAS CM., COPIUS-PEEREBOOM JH., et al. The impact of calcium, magnesium, zinc, and copper in blood and seminal plasma on semen parameters in men. Reprod. Toxicol. 2001; 15(2):131-6.

5. RYZEN E., RUDE RK. Low intracellular magnesium in patients with acute pancreatitis and hypocalcemia. West J Med. 1990; 152(2): 145.

6. LU SY., HUANG ZM., HUANG WK., LIU XY., CHEN YY., SHI T., et al. How calcium inhibits the magnesium-dependent kinase gsk3ß: A molecular simulation study. Proteins: 2013; 81(5):740-53.

7. EL AALEBA., ABDO HM., ELSHAHED AR., BAYOUMI IM., HAMDY MHM. Measuement of seminal and serum plasma magnesium levels in premature ejaculation. The Gulf Journal of Dermatology and Venereology (GJDV). 2012; 20(2):35-9.

8. HALLIWELL B., GUTTERIDGE JMC. The chemistry of free radicals and related reactive species. Free Radicals in Biology and Medicine. Oxford Science Publications; p. 36- 104.

9. KEBEISH R., EL-AYOUTY Y., HUSAIN A. Effect of copper on growth, bioactive metabolites, antioxidant enzymes and photosynthesis-related gene transcription in Chlorella vulgaris. World Journal of Biology and Biological Sciences (WJBBS). 2014; 2(2):34-43.

10. LIU Z., CHEN L., SHANG Y., HUANG P., MIAO L. The micronutrient element zinc modulates sperm activation through the SPE-8 pathway in Caenorhabditis elegans. Development. 2013; 140(10):2103-7.

11. VILLAVERDE AIS., FIORATTI EG., RAMOS RS., NEVES RC., FERREIRA JCP., CARDOSO GS., et al. Blood and seminal plasma concentrations of selenium, zinc and testosterone and their relationship to sperm quality and testicular biometry in domestic cats. Anim Reprod Sci. 2014; 150(1):50-5.

12. KUMAR N., VERMAR P., SINGH LP., VARSHNEY VP., DASS RS. Effect of different levels and sources of zinc supplementation on quantitative and qualitative semen attributes and serum testosterone level in crossbred cattle (Bosindicus \$1 bf times \$ Bostaurus) bulls. Reprod Nutr Dev. 2006; 46(6):663-75.

13. KABATA-PENDIAS A., MUKHERJEE AB. Trace elements from soil to human. New York: Springer-Verlag; 2007. 
14. MADDING CI., JACOB M., RAMSAY V., SOKOL R. Serum and semen zinc levels in normozoospermic and oligozoospermic men. Ann Nutr Metab. 1986; 30(4):213-8.

15. BRAUGHLER JM., DUNCAN LA., CHASE RL. The involvement of iron in lipid peroxidation. Importance of ferric to ferrous ratios in initiation. J Biol Chem. 1986; 261(22):10282-9.

16. EIDI M., EIDI A., POUYAN O., SHAHMOHAMMADI P., FAZAELI R., BAHAR M. Seminal plasma levels of copper and its relationship with seminal parameters. Iran J Reprod Med. 2010; 8(2):60-5.

17. YAN L., QIAOYAN G., MINGCAI L., MENGYANG L., XUEMING G. Cadmium, Chromium, and Copper Concentration plus Semen-Quality in Environmental Pollution Site, China. Iran J Public Health. 2014; 43(1):35-41.

18. AYDEMIR B., KIZILER AR., ONARAN I., ALICI B., OZKARA H., AKYOLCU MC. Impact of Cu and Fe concentrations on oxidative damage in male infertility. Biol Trace Elem Res. 2006; 112(3):193-203.

19. YUYAN L., JUNQING W., WEI Y., WEIJIN Z., ERSHENG G. Are serum zinc and copper levels related to semen quality? Fertilsteril. 2008; 89(4):1008-11.

20. HALLIWELL B., GUTERRIDGE MC. Biologically relevant metal ion-dependent hydroxyl radical generation. FEBS Lett. 1992; 307:108-112

21. MARZEC-WRÓBLEWSKA U., KAMIŃSKI P., ŁAKOTA P., SZYMAŃSKI M., WASILOW K., LUDWIKOWSKI G., et al. Zinc and iron concentration and SOD activity in human semen and seminal plasma. Biol Trace Elem Res. 2011; 143(1):167-77.

22. KASPERCZYK A., DOBRAKOWSKI M., HORAK S., ZALEJSKA-FIOLKA J., BIRKNER E. The influence of macro and trace elements on sperm quality. J Trace Elem Med Biol. 2015; 30:153-9.

23. ALOOSH M., HASSANI M., NIKOOBAKHT M. Seminal plasma magnesium and premature ejaculation: a case-control study. BJU international. 2006; 98(2):402-4.

24. ATIG F., RAFFA M., ALI HB., ABDELHAMID K., SAAD A., AJINA M. Altered antioxidant status and increased lipid peroxidation in seminal plasma of Tunisian infertile men. Int J Biol Sci. 2012; 8(1):139-149.

25. ATIG F., RAFFA M., HABIB B-A., KERKENI A., SAAD A., AJINA M. Impact of seminal trace element and glutathione levels on semen quality of Tunisian infertile men. BMC urology. 2012; 12(1):6.

26. SAGLAM HS., ALTUNDAG H., ATIK YT., DUNDAR MŞ., ADSAN Ö. Trace elements levels in the serum, urine, and semen of patients with infertility. Turk J Med Sci. 2015; 45(2).

27. CAMEJO MI., ABDALA L., VIVAS-ACEVEDO G., LOZANO-HERNÁNDEZ R., ANGELI-GREAVES M., GREAVES ED. Selenium, copper and zinc in seminal plasma of men with varicocele, relationship with seminal parameters. Biol Trace Elem Res. 2011; 143(3):1247-54.

Received July 23, 2017 